\title{
PENDEKATAN INTEGRATIF DALAM PENANGGULANGAN TINDAK PIDANA KORUPSI
}

\author{
Mahmud Mulyadi \\ Fakultas Hukum Universitas Sumatera Utara \\ mulyadi_mahmud@yahoo.com
}

\begin{abstract}
The criminal act of corruption is one of the extraordinary crimes that have not been successfully eradicated in Indonesia. The basis for the eradication of corruption is stipulated in Law Number 31 Year 1999 concerning the Eradication of Corruption, amended by Law Number 20 Year 2001. The crime prevention policy as part of law enforcement policy should be able to place every component of the legal system in a conducive direction and applicative. The regulation of corruption in UUPTPK above is sufficient to ensnare the perpetrators of corruption. However, it still needs to be evaluated by taking into account international developments on the regulation of corruption. So the solution offered is the policy of combating corruption crimes must be done integrally. This integrative approach can be done through two approaches, namely penal approach and nonpenal approach.
\end{abstract}

Keywords: integrative approaches, criminal acts, corruption

\begin{abstract}
Abstrak, Tindak pidana korupsi merupakan salah satu kejahatan luar biasa yang belum berhasil diberantas di Indonesia. Dasar pemberantasan tindak pidana korupsi diatur dalam Undang-Undang Nomor 31 Tahun 1999 tentang Pemberantasan Tindak Pidana Korupsi, diubah melalui Undang-Undang Nomor 20 Tahun 2001. Kebijakan penanggulangan kejahatan sebagai bagian dari kebijakan penegakan hukum harus mampu menempatkan setiap komponen sistem hukum dalam arah yang kondusif dan aplikatif. Pengaturan tindak pidana korupsi dalam UUPTPK di atas sudah cukup memadai untuk menjerat pelaku-pelaku korupsi. Namun masih perlu dievaluasi dengan memperhatikan perkembangan internasional tentang pengaturan tindak pidana korupsi. Maka solusi yang ditawarkan adalah kebijakan penanggulangan kejahatan korupsi harus dilakukan secara integratif. Pendekatan yang integratif ini dapat dilakukan melalui dua pendekatan, yaitu pendekatan penal dan pendekatan nonpenal.
\end{abstract}

Kata Kunci:pendekatan integratif, tindak pidana, korupsi

\section{Pendahuluan}

Sejak diundangkannya Undang-Undang Nomor 31 Tahun 1999 tentang Pemberantasan Tindak Pidana Korupsi pada tanggal 16 Agustus 1999, kemudian undangundang tersebut diubah melalui Undang-Undang Nomor 20 Tahun 2001 tentang Perubahan atas Undang-Undang Nomor 31 Tahun 1999 tentang Pemberantasan Tindak Pidana Korupsi yang diundangkan tanggal 21 November 2001 (selanjutnya ditulis UUPTPK), pemberantasan tindak pidana korupsi belum juga mencapai titik keberhasilan yang diharapkan di Indonesia. 
Korupsi bukanlah masalah yang baru karena sejak dari dahulu korupsi telah mewarnai berbagai kehidupan masyarakat Indonesia. Secara sinis sebuah jurnal asing menyatakan bahwa "corruption is way of life in Indonesia". Komentar ini sangat pedas dan menyakitkan tetapi jauh hari sebelumnya Bung Hatta di tahun 60-an pernah mengemukakan bahwa korupsi di Indonesia sudah membudaya. Pernyataan Bung Hatta ini mungkin telah menjadi suatu kenyataan yang sulit dibantah sekarang ini karena skala korupsi yang terjadi pada beberapa tahun terakhir semakin menggila. ${ }^{1}$

Tindak pidana korupsi tidak pernah habis bahkan tumbuh subur, semakin ditindak semakin meluas, bahkan perkembangannya terus meningkat dari tahun ke tahun, baik dalam jumlah kasus, jumlah kerugian keuangan negara maupun kualitasnya. Modus operandinya semakin terpola dan tersistematis, lingkupnya pun telah merambah ke seluruh aspek kehidupan masyarakat dan lintas batas negara, korupsi secara nasional disepakati tidak saja sebagai kejahatan luar biasa (extra ordinary crime) dan kejahatan transnasional. $^{2}$

Banyak negara-negara berkembang yang mengalami kerugian karena tindak pidana korupsi, oleh sebab itu, masalah korupsi sebagai hal yang harus mendapat perhatian serius. ${ }^{3}$ Beberapa negara menginginkan agar perampasan aset korupsi diperlakukan sebagai hak yang tidak bisa dihapus atau dicabut. ${ }^{4}$ Aset korupsi merupakan hak negara yang harus dikembalikan kepada negara dan negara lah yang berhak untuk mengelola aset atau kekayaan negara dan dipergunakan sebesar-besarnya untuk kemakmuran dan kesejahteraan rakyat.

Indonesia dalam menangani kasus-kasus korupsi selama ini cenderung mengutamakan cara melalui jalur pidana yang lebih berfokus pada penghukuman terhadap pelaku tindak pidana korupsi dari pada pengembalian aset negara, namun kenyataannya, jalur pidana tidak cukup ampuh untuk meredam, mencegah, memberantas, dan mengurangi jumlah tindak pidana korupsi. Oleh karena itu dibutuhkan suatu kebijakan penanggulangan kejahatan korupsi (criminal policy) yang mengintegrasikan pendekatan hokum pidana (penal policy) dan pendekatan tanpa menggunakan hukum pidana (non penal policy).

${ }^{1}$ Sudirman Said dan Nizar Suhendra, Korupsi dan Masyarakat Indonesia dalam Mencuri Uang Rakyat, 16 Kajian Korupsi di Indonesia, Buku I Dari Puncak sampai Dasar. Hamid Basyaib et.al (Ed). (Jakarta: Yayasan Aksara, 2002), hlm. 97-98. Meskipun banyak ditentang oleh ahli kebudayaan, fakta-fakta menunjukan bahwa perilaku korup telah menjadi keseharian kita. Perbuatan yang diulang-ulang dan menjadi bagian dari kehidupan keseharian kita, tentu pantas menjadi bagian dari kebudayaan.

${ }^{2}$ Marwan Effendy, Pengadilan Tindak Pidana Korupsi, Lokakarya, (Surabaya: Antikorupsi bagi Jurnalis, 2007), hlm. 1.

${ }^{3}$ Purwaning M. Yanuar (2007), Pengembalian Aset Hasil Korupsi Berdasarkan Konvensi PBB Anti Korupsi 2003 Dalam Sistem Hukum Indonesia, (Bandung : Alumni, 2007), hlm. 10.

${ }^{4}$ Ibid., hlm. 10-11. Istilah yang tidak dapat dihapus dan dicabut diacu kepada konsep hakhak yang sama sekali tidak dapat dipisahkan dari pemilik hak tersebut. Dimana hak ini melekat pada diri manusia tanpa perlu adanya pengakuan. Beberapa Filsuf menyatakan bahwa siapa pun yang menyangkal hak-hak ini adalah salah. Teori hukum alam dari John Locke didasarkan pada gagasan bahwa setiap individu memiliki hak dasar tertentu yang tidak dapat dihapus atau dicabut sepanjang menyangkut kehidupan, kemerdekaan, dan kekayaan. 


\section{Criminal Policy sebagai Kebijakan Penanggulangan Tindak Pidana Korupsi}

Tindak pidana korupsi dapat mendatangkan kerugian bagi kehidupan berbangsa dan bernegara, serta mengganggu stabilitas perekonomian Indonesia. Oleh karena itu, pemerintah selaku penyelenggara kehidupan bernegara perlu memberikan perlindungan dan kesejahteraan masyarakat melalui berbagai kebijakan yang teragenda dalam program pembangunan nasional. Kebijakan pemerintah ini tergabung dalam kebijakan sosial (social policy). Kebijakan sosial dapat berupa kebijakan di bidang politik, ekonomi, hukum, perpajakan, pertahanan keamanan, pengelolaan sumber daya alam, perumahan yang layak, kesehatan lingkungan kehidupan dan lain sebagainya, yang berpengaruh pada peningkatan kualitas kehidupan masyarakat. ${ }^{5}$

Salah satu bagian dari kebijakan sosial ini adalah kebijakan penegakan hukum (law enforcement policy), termasuk di dalamnya kebijakan legislatif (legislative policy). Sedangkan kebijakan penanggulangan kejahatan (criminal policy) itu sendiri merupakan bagian dari kebijakan penegakan hukum (law enforcement policy). Kebijakan penegakan hukum (law enforcement policy) harus melihat cakupan yang luas yang terkandung dalam suatu sistem hukum (legal system). Menurut Friedman sistem hukum memiliki cakupan yang lebih luas dari hukum itu sendiri. Kata "hukum" sering mengacu hanya pada aturan dan peraturan. Sedangkan sistem hukum membedakan antara aturan dan peraturan itu sendiri, serta struktur, lembaga dan proses yang mengisinya. ${ }^{6}$ Oleh karena itu, bekerjanya hukum di dalam suatu sistem menurut Friedman ditentukan oleh tiga unsur, yaitu struktur hukum (legal structure), ${ }^{7}$ substansi hukum (legal substance), ${ }^{8}$ dan budaya hukum (legal culture) ${ }^{9}$

Ketiga unsur sistem hukum ini mempunyai hubungan dan peranan yang tak terpisahkan. Ketiganya adalah satu kesatuan yang menggerakan sistem hukum tersebut sehingga dapat berjalan dengan lancar. Struktur hukum dapat diibaratkan sebagai mesin yang menghasilkan sesuatu. Substansi hukum adalah sesuatu yang dihasilkan oleh mesin tersebut, sedangkan budaya hukum adalah siapa yang memutuskan untuk menghidupkan atau mematikan mesin dan membatasi penggunaan mesin tersebut. ${ }^{10}$ Jadi apabila salah

${ }^{5}$ Diana M. DiNitto Social Welfare, Politics and Public Policy. (Boston: Allyn \& Bacon, 2000), hlm. 2.

${ }^{6}$ Lawrence M. Friedman American Law an Introduction. (Selanjutnya disebut buku I). (New York: W.W. Norton \& Company, 1984), hlm. 4.

${ }^{7}$ Lawrence Friedman. The Legal System; A Social Science Perspective. (Selanjutnya di sebut buku II). (New York: Russel Sage Foundation, 1975), hlm. 14. The structure of a system is its skeletal framework, it is the permanent shape, the institutional body of system, the thought, rigid bones that keep the process flawing within bound".

${ }^{8}$ Lawrence M. Friedman (Buku I), Op. Cit., hal 6. Substansi hukum (legal substance) adalah aturan, norma dan pola perilaku nyata manusia yang berada di dalam sistem tersebut. Substansi juga berarti produk yang dihasilkan oleh orang-rang yang berada di dalam sistem hukum itu, baik berupa keputusan yang mereka keluarkan, maupun juga aturan-aturan baru yang mereka susun. Penting di ingat bahwa substansi hukum ini tidak hanya terpusat pada hukum yang tertulis saja (law in the book), tetapi juga mencakup hukum yang hidup di masyarakat (the living law).

${ }^{9}$ Ibid, hlm. 7. Unsur yang terakhir, yaitu budaya hukum (legal culture) adalah; "people's attitudes toward law and the legal system-their beliefs, values, ideas and expectations. In other words, it is that part of the general culture which concerns the legal system."

${ }^{10}$ Ibid. 
satu dari ketiga unsur sistem hukum ini sakit, maka akan menyebabkan sub sistem lainnya terganggu.

Kebijakan penanggulangan kejahatan (criminal policy) sebagai bagian dari kebijakan penegakan hukum (law enforcemen policy) harus mampu menempatkan setiap komponen sistem hukum dalam arah yang kondusif dan aplikatif untuk menanggulangi kejahatan, termasuk peningkatan budaya hukum masyarakat sehingga mau partisipasi yang aktif dalam penanggulangan kejahatan. Kerterlibatan masyarakat ini sangat penting karena menurut G. Pieter Hoefnagels bahwa kebijakan penanggulangan kejahatan (criminal policy) merupakan usaha yang rasional dari masyarakat sebagai reaksi mereka terhadap kejahatan. Selanjunya dikatakan bahwa kebijakan penanggulangan kejahatan merupakan ilmu untuk menanggulangi kejahatan. ${ }^{11}$ Oleh karena itu kebijakan penanggulangan kejahatan harus dilakukan melalui perencanaan yang rasional dan menyeluruh sebagai respon terhadap kejahatan (a rational total of the responses to crime). Kebijakan ini termasuk bagaimana mendesain tingkah laku manusia yang dapat dianggap sebagai kejahatan (criminal policy of designating human behavior as crime). ${ }^{12}$

Kebijakan penanggulangan kejahatan (criminal policy) menurut Hoefnagels dapat dilakukan dengan memadukan upaya penerapan hukum pidana (criminal law application), pencegahan tanpa menggunakan hukum pidana (prevention without punishment) dan upaya mempengaruhi pandangan masyarakat terhadap kejahatan dan pemidanaan melalui media massa (influencing views of society on crime and punishment (mass media). ${ }^{13}$

Berdasarkan teori yang dikemukakan oleh G. Pieter Hoefnagels di atas, maka kebijakan penanggulangan kejahatan dapat disederhanakan melalui dua cara. Pertama, kebijakan penal (penal policy) yang biasa disebut dengan "criminal law application." Kedua, kebijakan non-penal (non-penal policy) yang terdiri dari "prevention without punishment" dan "influencing views of society on crime and punishment (mass media)."

Pendekatan integral antara penal policy dan non penal policy dalam penanggulangan kejahatan harus dilakukan karena pendekatan penerapan hukum pidana semata mempunyai berbagai keterbatasan. Terdapat dua sisi yang menjadi keterbatasan hukum pidana ini. ${ }^{14}$ Pertama, dari sisi hakikat terjadinya suatu kejahatan. Kejahatan sebagai suatu masalah yang berdimensi sosial dan kemanusian disebabkan oleh berbagai faktor yang kompleks dan berada di luar jangkauan hukum pidana. Jadi, hukum pidana tidak akan mampu melihat secara mendalam tentang akar persoalan kejahatan ini bila tidak dibantu oleh disiplin lain. Untuk itulah hukum pidana harus terpadu dengan pendekatan sosial.

Kedua, keterbatasan hukum pidana dapat dilihat dari hakikat berfungsinya hukum pidana itu sendiri. Penggunaan hukum pidana pada hakikatnya hanya obat sesaat sebagai penanggulangan gejala semata (Kurieren am symtom) dan bukan alat penyelesaian yang

${ }^{11}$ G. Pieter Hoefnagels The Other Side of Criminology, An Inversion of The Concept of Crime. (Holland: Kluwer Deventer, 1972), hlm. 57.

12 Ibid., hlm. 99-100

${ }^{13}$ Ibid., hlm. 56.

14 Barda Nawawi Arief, Beberapa Aspek Kebijakan Penegakan dan Pengembangan Hukum Pidana. (Selanjutnya disebut buku I). (Bandung: Citra Aditya Bakti, 1998), hlm. 44 - 45. 
tuntas dengan menghilangkan sumber penyebab penyakitnya. Dalam konteks ini, hukum pidana berfungsi setelah kejahatan terjadi. Artinya hukum pidana tidak memberikan efek pencegahan sebelum kejahatan itu terjadi, sehingga hukum pidana tidak mampu menjangkau akar kejahatan itu sendiri yang berdiam di tengah kehidupan masyarakat.

Sanksi hukum pidana selama ini bukanlah obat (remedium) untuk memberantas sumber penyakit (kejahatan), tetapi hanya sekedar untuk mengatasi gejala atau akibat dari penyakit tersebut. Dengan kata lain, sanksi hukum pidana bukanlah suatu pengobatan yang kausatif, tetapi hanya sekedar pengobatan yang simptomatik. ${ }^{15}$

Penjatuhan sanksi pidana kepada pelaku kejahatan diharapkan memberikan pencegahan kepada masyarakat dan pelaku sendiri untuk tidak berbuat kejahatan kembali. Namun, tujuan ini terkadang mengalami kegagalan, sehingga terkadang pelaku justru menjadi resedivis dan masyarakat sendiri dapat meniru untuk melakukan kejahatan. Hal ini juga karena penerapan sanksi pidana tidak melihat akar persoalan kejahatan yang sebenarnya. Oleh karena itu butuh pendekatan sosial di samping penerapan sanksi pidana.

Keterbatasan pendekatan penal dalam upaya penanggulangan kejahatan seperti dikemukakan di atas, harus diikuti dengan pendekatan non-penal, yang dapat berupa pencegahan tanpa menggunakan hukum pidana (prevention without punishment) dan upaya mempengaruhi pandangan masyarakat terhadap kejahatan dan pemidanaan melalui media massa (influencing views of society on crime and punishment/mass media).

Kebijakan penanggulangan kejahatan lewat jalur non penal lebih bersifat tindakan pencegahan untuk terjadinya suatu kejahatan. Oleh karena itu, sasaran utamanya adalah menangani faktor-faktor kondusif penyebab terjadinya kejahatan yang berpusat pada masalah-masalah atau kondisi-kondisi sosial yang secara langsung atau tidak langsung dapat menimbulkan atau menumbuhsuburkan kejahatan. Dengan demikian dilihat dari kebijakan penanggulangan kejahatan, maka usaha-usaha non penal ini mempunyai kedudukan yang strategis dan memegang peranan kunci yang harus diintensifkan dan diefektifkan. ${ }^{16}$

\section{Pendekatan Integral antara Penal Policy dan Non Penal Policy dalam Pemberantasan Tindak Pidana Korupsi}

Pada hakikatnya kebijakan penanggulangan kejahatan (termasuk tindak pidana korupsi) dapat dilakukan melalui dua pendekatan, yaitu pendekatan penal (penerapan hukum pidana) dan pendekatan nonpenal (pendekatan di luar hukum pidana). Integrasi

15 Ibid. , (Buku I) hlm. 44 - 45. Pengobatan simptomatik melalui sanksi pidana ini mengandung banyak kelemahan sehingga masih dipersoalkan keefektifannya. Di samping itu juga, pengobatan melalui sanksi pidana itu sendiri mengandung juga sifat-sifat yang kontradiktif (paradoksal) dan unsur-unsur negatif yang dapat membahayakan atau setidak-tidaknya dapat menimbulkan efek-efek sampingan yang negatif.

${ }^{16}$ Ibid., (Buku I) hlm. 33. Baca juga Barda Nawawi Arief Bunga Rampai Kebijakan Hukum Pidana. (Selanjutnya disebut buku II). (Bandung: Citra Aditya Bakti, 1996), hlm. 4. Senada dengan persoalan di atas, Barda Nawawi Arief menyatakan bahwa penanggulangan kejahatan harus dilakukan secara integral melalui kebijakan, dalam arti:

1. Kebijakan penanggulangan kejahatan merupakan bagian dari keseluruhan kebijakan sosial (kebijakan pembangunan nasional);

2. Harus ada keterpaduan antara upaya penanggulangan kejahatan dengan menggunakan sarana penal dan non-penal. 
dua pendekatan ini disyaratkan dan diusulkan dalam United Nations Congress on the Prevention of Crime and the Treatment of Offenders. Hal ini dilatarbelakangi bahwa kejahatan adalah masalah sosial dan masalah kemanusiaan. Oleh karenanya upaya penanggulangan kejahatan tidak hanya dapat mengandalkan penerapan hukum pidana semata, tetapi juga melihat akar lahirnya persoalan kejahatan ini dari persoalan sosial, sehingga kebijakan sosial juga sangat penting dilakukan.

Kongres PBB Ke- 4 Tahun 1970 di Kyoto, Jepang, menyatakan bahwa terdapat keterkaitan antara kejahatan dengan pembangunan, namun semua ini tergantung pada proses pembangunan di suatu negara. Oleh karena itu perencanaan perlindungan sosial harus terintegrasi dalam perencanaan pembangunan nasional. Lebih rinci dinyatakan: "The view that social defence planning should be an integral and essential part of planning for national development was accepted without question. Planning should provider for the total well-being of the community..."17

Dalam kesimpulan pembahasan pada Kongres PBB Ke-4 ini, yang menyangkut "Social Defence Policies in Relation to Development planning," ditegaskan: "Social defence planning should be an integral part of national planning. No country can efford to exclude the social defence element in its over-all social and economic planning and its allocation of adequate resources to that end. The prevention of crime and the treatment of offenders effectively undertaken unless it is closely and intimately related to social and economic trends. Social and economic planning would be unrealistic if it did not seek to neutralize criminogenic potential by the appropriate investment in development programmes." 18

Sedangkan Kongres Ke-5 PBB Tahun 1975 di Geneva, menekankan pentingnya pemikiran kembali dalam jangka panjang tentang kebijakan penanggulangan kejahatan secara komprehensif dalam semangat yang rasional, demokratis dan terencana (...it was necessary, in long term, to rethinking the whole of criminal policy in a spirit of rationalization, planning and democratization). ${ }^{19}$ Selanjutnya dinyatakan dalam Kongres Ke-5 PBB ini; "Criminal policy was an aspect of social policy and its planning therefore had to be integrated into that of general progress of community... crime prevention policy was one aspect of general social policy and hence should be integrated into a country's development planning as a whole." 20

Akhirnya Kongres PBB ke-5 ini menyimpulkan bahwa berbagai aspek dari kebijakan penanggulangan kejahatan harus dikoordinasikan dan secara keseluruhan harus terintegrasi dalam kebijakan sosial pada setiap negara (The many aspects of criminal policy should be coordinated and the whole should be integrated into general social policy of each country). ${ }^{21}$

${ }^{17}$ Fourth United Nations Congress on the Prevention of Crime and the Treatment of Offenders. (New York: Departement of Economic and Social Affairs, UN, 1971), hlm. 9.

18 Ibid., hlm. 13.

19 Fifth United Nations Congress on the Prevention of Crime and the Treatment of Offenders. (New York: Departement of Economic and Social Affairs, UN, 1976), hlm. 20.

${ }^{20}$ Ibid., hlm. 21.

${ }^{21}$ Ibid., Hal. 25 
Pentingnya keterpaduan antara kebijakan penanggulangan kejahatan dengan rencana pembangunan, ditegaskan kembali pada Kongres PBB Ke-6 Tahun 1980 di Caracas. Kongres ini menghasilkan Deklarasi Caracas yang menekankan keterkaitan secara integral antara Sistem Peradilan Pidana (Criminal Justice System) dan kebijakan penanggulangan kejahatan, yang harus terpadu dengan kebijakan pembangunan ekonomi, politik dan sosial budaya.

Berkaitan dengan kebijakan penanggulangan kejahatan ini, maka Deklarasi Caracas menyatakan lebih rinci, sebagai berikut: ${ }^{22}$

"Crime prevention and criminal justice should be considered in the context of economic development, political system, social and cultural values and social change, as well as in the context of the new international economic order;

It is matter of great importance and priority that program's for crime prevention and treatment of offenders should be based on the social cultural, political and economic circumstances of each country, in a climate of freedom and respect for human right, that member states should develop an effective capacity for the formulation and planning of criminal policy, and that all crime prevention policies should be co-coordinated with strategies for social, economic, politic and cultural development;

Criminal policy and the administration of justice should be based on principles that will quarantee the equality of everyone before the law without any discrimination...;

Continuous effort should be made to seek new approaches and to develop better tehniques for crime prevention and the treatment of offenders, and to that end, criminal law should be developed in such a way as to play an effective and important role in creating stable social conditions free from oppression and manipulation."

Kongres PBB Ke-7 Yahun 1985 di Milan tentang Guiding Principles for Crime Prevention and Criminal Justice in the Context of Development and a New International Economic Order, juga menyatakan harus adanya keterpaduan kebijakan penanggulangan kejahatan dengan kebijakan di bidang ekonomi, politik dan budaya sebagai bagian dari kebijakan sosial. Secara rinci, hal ini di nyatakan sebagai berikut:

"Crime prevention and criminal justice should not be treated as isolated problem to be tackled by simplistic, fragmentary method, but rather as complex and wideranging activities requiring systematic strategies and differentiated in relation to:

(a) The socio-economic, political and cultural contect and circumstances of the society in which they are applied;

(b) The development stage, which special emphasis on the changes taking place and likely to occur and related requirements;

(c) The respective tradition and customs, making maximum and effective use of human indigeneus options." 23

${ }^{22}$ Sixth United Nations Congress. on the Prevention of Crime and the Treatment of Offenders. (New York: Departement of Economic and Social Affairs, UN, 1981), hlm. 25.

${ }^{23}$ Seventh United Nations Congress on the Prevention of Crime and the Treatment of Offenders. (New York: Departement of Economic and Social Affairs, UN, 1986), hlm. 9. 
Keseluruhan kesepakatan dan himbauan Kongres-Kongres PBB di atas mengenai keterpaduan kebijakan penanggulanagn kejahatan dengan kebijakan sosial dan rencana pembangunan, ditegaskan kembali dalam Kongres PBB Ke-8 Tahun 1990 di Havana. Di dalam Kongres ini dinyatakan:

"Convinced that crime prevention and criminal justice in the context of development should be oriented towards the observance of the principles contained in the Caracas Declaration, The Milan Plan of Action, The Guiding Principles for Crime Prevention and Criminal Justice in the Context of Development and a New International Economic Order and other relevan resolutions and recommendations of Seventh United Nations Congress on the Prevention of Crime and the Treatment of Offenders." ${ }^{4}$

Pendekatan integral dalam kebijakan penanggulangan kejahatan, juga ditegaskan dalam The International Seminar Course yang diselenggarakan oleh UNAFEI. W. Clifford menyatakan dalam Seminar Internasional ke-32 UNAFEI Tahun 1973 di Jepang tentang Reform in Criminal Justice, sebagai berikut: ${ }^{25}$

"On the one hand there is the need for a wider view of criminal policy as an integral part of general political and social policy of a given country. It is a reflection of local mores and customs and a by product of development. From this wider view point, criminal policy cannot be something a part from the more general social situation but must be developed from it and throught it."

Selanjutnya Karl O. Christiansen dalam Seminar International UNAFEI Tahun 1974, menyatakan sebagai berikut: "Criminal policy must combine the various preventive and adjust them so as to from a single comprehensif machine and finally coordinate the whole into an organized system of state activity". ${ }^{26}$

Sedangkan dalam Report on Investigation and Crime Prevention, UNAFEI, ditegaskan bahwa pendekatan integral dalam kebijakan penanggulangan kejahatan harus dilaksanakan karena kejahatan mempunyai dimensi sosial dan dimensi kemanusian. Hal ini dinyatakan sebagai berikut; "It is generally accepted that crime is a function of myriad of human and social conditions, that causation of crime is multi-factoral as it is multyfaceted and that prevention strategies are likewise multi-dimensional..."27

Seminar UNAFEI ini juga perlu menekankan kembali hasil-hasil yang telah dicapai dalam Deklarasi Caracas, tahun 1980 pada Kongres PBB Ke-7, yaitu mengenai pendekatan integral kebijakan penanggulangan kejahatan dengan kebijakan pembangunan nasional.

Akhirnya, dalam kesimpulan Seminar UNAFEI ini dinyatakan bahwa efektifitas dan efisensi investigasi dan upaya penanggulangan kejahatan harus dicapai melalui dukungan keseluruhan masyarakat. Lebih jelas dinyatakan; "It must always be

${ }^{24}$ Eigth United Nations Congress, on on the Prevention of Crime and the Treatment of Offenders. (New York: Departement of Economic and Social Affairs, UN, 1986), hlm. 9.

${ }^{25}$ W. Clifford, Reform in Criminal Justice in Asia and the Far East. Tokyo: UNAFEI, Resource Material Series No. 6, 1973. hlm. 7.

${ }^{26}$ Karl O. Christiansen, Some Consideration on the Possibility of a Rational Criminal Policy. Tokyo: UNAFEI, Resource Material Series No. 7, 1974, hlm. 74.

${ }^{27}$ UNAFEI, Tokyo: Resource Material Series No. 22, hlm. 77. 
remembered that efficient and effective investigation and crime prevention strategies depend, in a great measure, an the support and cooperation the community offers. " 28

Berdasarkan uraian-uraian di atas, maka keberhasilan penanggulangan kejahatan harus disyaratkan pada integralitas berbagai pendekatan, yang secara garis besarnya dapat kita bagi menjadi pendekatan penal, melalui penerapan hukum pidana dan upaya nonpenal, yaitu kebijakan penanggulangan tanpa penerapan hukum pidana, melainkan dititik tekankan pada berbagai kebijakan sosial.

\section{Penal Policy dalam Pemberantasan Tindak Pidana Korupsi}

Istilah "kebijakan" berasal dari bahasa Inggris "policy" atau bahasa Belanda "politiek". Istilah ini dalam bahasa Indonesia sering diterjemahkan dengan kata "politik", oleh karena itu kebijakan hukum pidana biasa disebut juga politik hukum pidana. Berbicara mengenai politik hukum pidana, maka tidak terlepas dari pembicaraan mengenai politik hukum secara keseluruhan karena hukum pidana adalah salah satu bagian dari ilmu hukum. Oleh karena itu sangat penting untuk dibicarakan tentang politik hukum.

Menurut Soedarto, politik hukum adalah usaha untuk mewujudkan peraturanperaturan yang baik dengan situasi dan kondisi tertentu. Secara mendalam dikemukakan juga bahwa politik hukum merupakan kebijakan negara melalui alat-alat perlengkapannya yang berwenang untuk menetapkan peraturan-peraturan yang dikehendaki dan diperkirakan dapat digunakan untuk mengekspresikan apa yang terkandung dalam masyarakat dalam rangka mencapai apa yang dicita-citakan. ${ }^{29}$

Berdasarkan pengertian tentang politik hukum sebagaimana dikemukakan di atas, maka secara umum dapat ditarik kesimpulan bahwa politik hukum pidana merupakan upaya menentukan ke arah mana pemberlakukan hukum pidana Indonesia masa yang akan datang dengan melihat penegakannya saat ini. Hal ini juga berkaitan dengan konseptualisasi hukum pidana yang paling baik untuk diterapkan. Lebih lanjut Sudarto mengungkapkan bahwa melaksanakan politik hukum pidana berarti mengadakan pemilihan dalam rangka mencapai hasil perundang-undangan pidana yang paling baik dengan memenuhi syarat keadilan dan dayaguna. ${ }^{30}$

A. Mulder mengemukakan secara rinci tentang ruang lingkup politik hukum pidana yang menurutnya bahwa politik hukum pidana adalah garis kebijakan untuk menentukan: (a) seberapa jauh ketentuan-ketentuan pidana yang berlaku perlu dilakukan perubahan atau diperbaharui; (b) apa yang dapat diperbuat untuk mencegah terjadinya kejahatan; (c)

${ }^{28}$ Ibid., hlm. 81

${ }^{29}$ Lihat Soedarto Hukum dan Hukum Pidana. (Bandung: Alumni, 1981). hlm. 159. Lihat juga Sudarto. Hukum Pidana dan Perkembangan Masyarakat. (Bandung: Sinar Baru, 1983), hlm. 20. Lihat juga Solly Lubis, Serba Serbi Politik dan Hukum. (Bandung: Mandar Maju, 1989), hlm. 49. Solly Lubis juga menyatakan bahwa politik hukum adalah kebijaksanaan politik yang menentukan peraturan hukum apa yang seharusnya berlaku mengatur berbagai hal kehidupan bermasyarakat dan bernegara.

${ }^{30}$ Sudarto, Op. Cit., hlm. 161. 
cara bagaimana penyidikan, penuntutan, peradilan dan pelaksanaan pidana harus dilaksanakan. ${ }^{31}$

Berdasarkan pengertian politik hukum pidana yang dikemukakan oleh A. Mulder di atas, maka ruang lingkup kebijakan hukum pidana ini sesungguhnya meliputi masalah yang cukup luas, yaitu meliputi evaluasi terhadap substansi hukum pidana yang berlaku saat ini untuk pembaharuan substansi hukum pidana pada masa yang akan datang, dan bagaimana penerapan hukum pidana ini melaui komponen Sistem Peradilan Pidana, serta yang tidak kalah pentingnya adalah upaya pencegahan terhadap kejahatan. Upaya pencegahan ini berarti bahwa hukum pidana juga harus menjadi salah satu instrumen pencegah kemungkinan terjadinya kejahatan. Ini juga berarti bahwa penerapan hukum pidana harus mempunyai pengaruh yang efektif untuk mencegah sebelum suatu kejahatan terjadi.

Substansi tindak pidana korupsi yang diatur dalam UU No. 31 Tahun 1999 sebagaimana yang diperbaharui dengan UU No. 20 Tahun 2001 tentang Pemberantasan Tindak Pidana Korupsi (selanjutnya disebut UU PTPK). Secara umum bentuk-bentuk tindak pidana korupsi yang diatur dalam UU PTPK dapat dikelompokan sebagai berikut:

1. Tindak Pidana Korupsi dengan Memperkaya Diri Sendiri, Orang Lain, atau Suatu Korporasi (Pasal 2)

2. Tindak Pidana Korupsi dengan Menyalahgunakan Kewenangan, Kesempatan, Sarana Jabatan, atau Kedudukan (Pasal 3)

3. Tindak Pidana Korupsi Suap dengan Memberikan atau Menjanjikan Sesuatu (Pasal 5)

4. Tindak Pidana Korupsi Suap pada Hakim dan Advokat (Pasal 6)

5. Korupsi dalam Hal Membuat Bangunan dan Menjual Bahan Bangunan dan Korupsi dalam Hal Menyerahkan Alat Keperluan TNI dan KNRI (Pasal 7)

6. Korupsi Pegawai Negeri Menggelapkan Uang dan Surat Berharga (Pasal 8)

7. Tindak Pidana Korupsi Pegawai Negeri Memalsu Buku-Buku dan Daftar-Daftar (Pasal 9)

8. Tindak Pidana Korupsi Pegawai Negeri Merusakkan Barang, Akta, Surat, atau Daftar (Pasal 10)

9. Korupsi Pegawai Negeri Menerima Hadiah atau Janji yang Berhubungan dengan Kewenangan Jabatan (Pasal 11)

10.Korupsi Pegawai Negeri atau Penyelenggara Negara atau Hakim dan Advokat Menerima Hadiah atau Janji; Pegawai Negeri Memaksa Membayar, Memotong Pembayaran, Meminta Pekerjaan, Menggunakan Tanah Negara, dan Turut Serta dalam Pemborongan (Pasal 12)

11.Tindak Pidana Korupsi Suap Pegawai Negeri Menerima Gratifikasi (Pasal 12B)

12.Korupsi Suap pada Pegawai Negeri dengan Mengingat Kekuasaan Jabatan (Pasal 13)

${ }^{31}$ Barda Nawawi Arief, Bunga Rampai Kebijakan Hukum Pidana. (Bandung: Citra Aditya Bakti, 1996), hlm. 28. 
Pengaturan tindak pidana korupsi dalam UUPTPK di atas sudah cukup memadai untuk menjerat pelaku-pelaku korupsi. Namun masih perlu dievaluasi dengan memperhatikan perkembangan internasional tentang pengaturan tindak pidana korupsi.

Perserikatan Bangsa-Bangsa (PBB), pada tahun 2003 membentuk sebuah konvensi yang dinamakan dengan Konvensi PBB Anti Korupsi 2003 United Nations Convention Against Corruption 2003 (UNCAC 2003). Pada tanggal 18 April 2006 KAK 2003 ini diratifikasi oleh pemerintah. ${ }^{32}$ UNCAC sangat berarti bagi Indonesia dalam memberantas tindak pidana korupsi, yaitu: ${ }^{33}$

a. Untuk meningkatkan kerja sama internasional khususnya dalam melacak, membekukan, menyita, dan mengembalikan aset-aset hasil tindak pidana korupsi yang ditempatkan di luar negeri;

b. Meningkatkan kerja sama internasional dalam mewujudkan tata pemerintahan Yang baik;

c. Meningkatkan kerja sama internasional dalam pelaksanaan perjanjian ekstradisi, bantuan hukum timbal balik, penyerahan narapidana, pengalihan proses pidana, dan kerja sama penegakan hukum;

d. Mendorong terjalinnya kerja sama teknik dan pertukaran informasi dalam pencegahan dan pemberantasan tindak pidana korupsi di bawah payung kerja sama pembangunan ekonomi dan bantuan teknis pada lingkup bilateral, regional, dan multilateral; dan

e. Harmonisasi peraturan perundang-undangan nasional dalam pencegahan dan pemberantasan tindak pidana korupsi sesuai dengan Konvensi ini.

Keprihatinan PBB terhadap masalah korupsi ini karena korupsi merupakan suatu ancaman terhadap stabilitas dan keamanan masyarakat, merusak lembaga-lembaga dan nilai-nilai demokrasi, nilai-nilai etika, dan keadilan serta menghambat pembangunan berkelanjutan (sustainable development) bagi negara-negara yang menghadapi fenomena korupsi. ${ }^{34}$ Bahkan fenomena korupsi saat ini disertai dengan tindak pidana lain terkait dengan upaya menyembunyikan aset-aset hasil korupsi melalui pencucian uang atau money laundering. ${ }^{35}$

Materi UNCAC 2003 tercermin suatu perubahan cara pandang terhadap multi aspek korupsi, antara lain: ${ }^{36}$

1. Masalah korupsi memiliki multi aspek, yakni: aspek hukum, HAM, pembangunan berkelanjutan, kemiskinan, dan keamanan;

${ }^{32}$ Ratifikasi UNCAC 2003 oleh pemerintah Indonesia yang secara politis menempatkan posisi Indonesia sebagai salah satu negara di Asia yang memiliki komitmen pemberantasan korupsi lewat kerjasama internasional, diharap mampu memberikan dorongan terutama bagi negara- negara lain yang kurang kooperatif dalam pengembalian aset hasil korupsi di Indonesia, di samping pula langkah Indonesia untuk mencegah dan mengembalikan aset hasil korupsi dari negara lain akan menjadi bagian dari agenda kerjasama internasional dalam upaya pemberantasan korupsi secara global.

${ }^{33}$ Penjelasan Undang-Undang Nomor Nomor 7 Tahun 2006 tentang Ratifikasi UNCAC 2003.

\footnotetext{
${ }^{34}$ Purwaning M. Yanuar, Op. cit., hlm. 1.

35 Ibid., hlm. 47.

${ }^{36}$ I. Gusti Ketut Ariawan, Loc. cit.
} 
2. Sistem pembuktian secara konvensional tidak selalu ampuh dalam pemberantasan korupsi, sehingga beban pembuktian terbalik merupakan solusi alternatif yang potensial.

Hal yang paling mendasar dalam UNCAC 2003 adalah kerja sama internasional di bidang perampasan aset (asset recovery). ${ }^{37}$ Disusul dengan diluncurkannya Stolen Asset Recovery (StAR) pada bulan Juni 2007 yang memuat challenges, opportunities dan action plan dalam upaya pengembalian aset hasil korupsi. StAR merupakan program bersama yang diluncurkan oleh Bank Dunia (World Bank) dan PBB khususnya United Nations Office on Drugs and Crimes (UNODC) bertujuan untuk meningkatkan kerja sama internasional dalam mengimplementasikan upaya pengembalian aset hasil korupsi sebagai salah satu terobosan dalam hukum internasional yang menetapkan landasan mengenai pengembalian aset hasil kejahatan korupsi di negara-negara sedang berkembang. ${ }^{38}$

\section{Non penal Policy dalam Penanggulangan Tindak Pidana Korupsi}

Kebijakan penanggulangan kejahatan lewat jalur "non penal" lebih bersifat tindakan pencegahan sebelum terjadinya kejahatan. Oleh karena itu, sasaran utamanya adalah menangani faktor-faktor kondusif penyebab terjadinya kejahatan yang berpusat pada masalah-masalah atau kondisi-kondisi sosial yang secara langsung atau tidak langsung dapat menimbulkan atau menumbuhsuburkan kejahatan. Dengan demikian dilihat dari kebijakan penanggulangan kejahatan, maka usaha-usaha non penal ini mempunyai kedudukan yang strategis dan memegang peranan kunci yang harus diintensifkan dan diefektifkan. ${ }^{39}$

Pernyataan di atas juga didukung oleh berbagai hasil dari Kongres PBB mengenai The Prevention of Crime and the Treatment of Offenders. Kongres PBB ke-6 Tahun 1980 yang berlangsung di Caracas, Venezuela menyatakan dalam pertimbangan resolusinya mengenai Crime Trends and Crime Prevention Strategies, antara lain: ${ }^{40}$

1. Bahwa masalah kejahatan merintangi kemajuan untuk pencapaian kualitas kehidupan yang layak bagi semua orang (the crime impedes progress towards the attainment of an acceptable quality of life for all people);

2. Bahwa strategi pencegahan kejahatan harus didasarkan pada penghapusan sebabsebab dan kondisi-kondisi yang menimbulkan kejahatan (crime prevention strategies should be based upon the elemination of causes and condition giving rise to crime);

${ }^{37}$ Chapter V Artikel 51 dan 57 UNCAC 2003.

38 http://go.worldbank.org/U2ZCWCDKR0, diakses tanggal 7 Februari 2011. StAR merupakan bagian integral dari Governance and Anti Corruption Strategy World Bank Group yang menyatakan perlunya bantuan bagi negara-negara berkembang dalam pengembalian asset. Progam yang diluncurkan oleh PBB ini sebenarnya terinspirasi dari keberhasilan Peru, Nigeria dan Filipina dalam mengembalikan aset-aset yang diinvestasikan di Negara lain oleh mantan kepala negaranya. Walaupun keberhasilan tersebut tidak mudah dan membutuhkan waktu yang relatif lama.

${ }^{39}$ Barda Nawawi Arief ,Op. Cit., hlm. 33.

${ }^{40}$ Sixth United Nations Congress, Op. Cit., hlm. 5. 
3. Bahwa penyebab utama banyaknya terjadi kejahatan diberbagai negara adalah disebabkan oleh ketimpangan sosial, diskriminasi rasial dan diskriminasi nasional, standar hidup yang rendah, pengangguran dan kebodohan diantara sebagain besar penduduk (the main causes of crime in many countries are social inequality, ratial and national discrimination, low standar of living, unemployment and illiteracy among broad section of the population).

Berdasarkan Pertimbangan di atas, maka di dalam Resolusi Kongres ke-6 PBB ini, dihimbau kepada semua anggota PBB untuk mengambil tindakan dalam kekuasaan mereka untuk menghapus kondisi-kondisi kehidupan yang menurunkan martabat kemanusiaan dan menyebabkan kejahatan yang meliputi masalah pengangguran, kemiskinan, kebutahurufan, diskriminasi rasial dan nasional serta berbagai macam bentuk ketimpangan sosial.

Di dalam Dokumen A/CONF. 121/L/9 mengenai Crime Prevention in the Context Of Development Kongres PBB ke-7 Tahun 1985 di Milan, Italia ditegaskan bahwa upaya penghapusan sebab-sebab dan kondisi yang menimbulkan kejahatan harus merupakan strategi pencegahan kejahatan yang mendasar. Strategi pencegahan kejahatan yang mendasar ini harus dicarikan untuk menghilangkan penyebab dan kondisi-kondisi yang menimbulkan suatu kejahatan.

Akhirnya di dalam Guiding Principles yang dihasilkan oleh Kongres PBB ke-7 ini, ditegaskan bahwa berbagai kebijakan mengenai pencegahan kejahatan dan peradilan pidana harus mempertimbangkan sebab-sebab struktural, termasuk sebab-sebab ketidakadilan yang bersifat sosio-ekonomi, dimana kejahatan sering merupakan suatu gejala semata (symptom). ${ }^{41}$

Kongres PBB ke-8 tahun 1990 yang berlangsung di Havana, Cuba, menekankan pentingnya aspek sosial dari kebijakan pembangunan yang merupakan suatu faktor penting dalam pencapaian strategi pencegahan kejahatan dan peradilan pidana. Oleh karena aspek-aspek social dalam kontek pembangunan ini harus mendapat prioritas yang utama. Kongres ke-8 ini juga berhasil mengidentifikasi berbagai aspek sosial yang ditengarai sebagai faktor-faktor kondusif penyebab timbulnya kejahatan. Hal ini disebutkan dalam Dokumen A/CONF. 144/L.3, yaitu sebagai berikut: ${ }^{42}$

1. Kemiskinan, pengangguran, kebutahurufan, ketiadaan perumahan yang layak dan sistem pendidikan serta pelatihan yang tidak cocok;

2. Meningkatnya jumlah penduduk yang tidak mempunyai prospek (harapan) karena proses integrasi sosial dan karena memburuknya ketimpangan-ketimpangan sosial;

3. Mengendornya ikatan sosial dan keluarga;

4. Keadaan-keadaan atau kondisi yang menyulitkan bagi orang yang berimigrasi ke kota-kota atau ke negara-negara lain;

5. Rusaknya atau hancurnya identitas budaya asli, yang bersamaan dengan adanya rasisme dan diskriminasi menyebabkan kelemahan di bidang sosial, kesejahteraan dan lingkungan pekerjaan;

6. menurunnya atau mundurnya kualitas lingkungan perkotaan yang mendorong peningkatan kejahatan dan tidak cukupnya pelayanan bagi tempat-tempat fasilitas lingkungan kehidupan bertetangga;

\footnotetext{
${ }^{41}$ Seventh United Nations Congress, Op. Cit., hlm. 15.

${ }^{42}$ Eigth United Nations Congress, Op. Cit., hlm. 3.
} 
7. kesulitan-kesulitan bagi orang-orang dalam masyarakat modern untuk berintegrasi sebagaimana mestinya di dalam lingkungan masyarakatnya, di lingkungan keluarga, tempat pekerjaannya atau dilingkungan sekolahnya;

8. Penyalahgunaan alkohol, obat bius dan lain-lain yang pemakaiannya juga diperluas karena faktor-faktor yang disebut di atas;

9. meluasnya aktivitas kejahatan yang terorganisir, khususnya perdagangan obat bius dan penadahan barang-barang curian;

10.dorongan-dorongan (khususnya oleh media massa) mengenai ide-ide dan sikapsikap yang mengarah pada tindakan kekerasan, ketidaksamaan (hak) atau sikapsikap tidak toleran.

Kondisi sosial yang ditengarai sebagai faktor penyebab timbulnya kejahatan, seperti yang dikemukakan di atas adalah masalah-masalah yang sulit dipecahkan bila hanya mengandalkan pendekatan penal semata. Oleh karena itulah, pemecahan masalah di atas harus didukung oleh pendekatan non penal berupa kebijakan social dan pencegahan kejahatan berbasiskan masyarakat.

Pendekatan non penal menurut Hoefnagels adalah pendekatan pencegahan kejahatan tanpa menggunakan sarana pemidanaan (prevention without punishment), yaitu antara lain perencanaan kesehatan mental masyarakat (community planning mental health), kesehatan mental masyarakat secara nasional (national mental health), social worker and child welfare (kesejahteraan anak dan pekerja social), serta penggunaan hukum civil dan hukum administrasi (administrative \& civil law). ${ }^{43}$

Pola tindak pidana korupsi bertitik tolak pada tingkah laku atau tindakan yang tidak bermoral, tidak etis dan atau melanggar hukum untuk kepentingan pribadi dan atau golongan yang merugikan keuangan negara, ${ }^{44}$ maka untuk memberantas tindak pidana korupsi tersebut, di samping mengoptimalkan hukum pidana, ${ }^{45}$ juga harus menggunakan sarana hukum perdata. Proses perdata dilakukan dalam pengembalian kerugian keuangan negara dengan menggunakan instrumen civil forfeiture yang merupakan amanah dari UNCAC 2003.

civil forfeiture menjadi suatu alternatif yang sangat baik apabila jalur pidana tidak berhasil. Bahkan dalam praktiknya, ditemukan bahwa prosedur civil forfeiture dinilai

${ }^{43}$ G. Peter Hoefnagels, Op. Cit., hlm. 56 dan 67. Dalam kontek ini, informasi yang diperoleh melalui disiplin lain, misalnya sosiologi, antropologi dan psikologi, sangat membantu untuk merumuskan kebijakan sosial, perencanaan kesehatan mental masyarakat sehingga memberikan pengaruh preventif terhadap terjadinya kejahatan. Selain itu juga, program-program untuk mengatasi tekanan (stress) dalam kehidupan bermasyarakat perlu mendapat perhatian dalam penanggulangan kejahatan, antara lain, kesejahteraan anak-anak serta rehabilitasi dan kesehatan pekerja sosial.

44 Juniadi Soewartojo, Korupsi, Pola Kegiatan dan Penindakannya Serta Peran Pengawasan Dalam Penanggulangannya, (Jakarta: Balai Pustaka, 1998), hlm. 5.

45 Romli Atmasasmita, Kapita Selekta Hukum Pidana dan Kriminologi, (Bandung: Mandar Maju, 1995), hlm. 135. Lihat juga: IGM Nurdjana., Sistem Hukum Pidana dan Bahaya Laten Korupsi "Perspektif Tegaknya Keadilan Melawan Mafia Hukum”, (Yogyakarta: Pustaka Pelajar, 2010), hlm. 12. Sistem peradilan pidana (criminal justice system) adalah suatu kesatuan proses pengadilan pidana yang tidak dapat dipisahkan antara satu sama lainnya dalam penegakan hukum pidana. 
lebih efektif dalam mengambil kembali aset-aset yang dicuri, meskipun prosedur ini tidak luput dari berbagai kelemahan seperti lambat dan biaya tinggi. ${ }^{46}$

Menurut Anthony Kennedey, implementasi civil forfeiture yang dilakukan di tiaptiap negara berbeda-beda. Civil forfeiture pada awalnya diterapkan dalam skala domestik, yaitu mengajukan gugatan perdata untuk menyita atau merampas atau mengambil alih aset-aset hasil kejahatan yang berada dalam negeri. Apabila aset hasil kejahatan berada di luar negeri, beberapa negara yang menggunakan civil forfeiture secara domestik mengaplikasikannya secara ekstra territorialitas. ${ }^{47}$

Sebagaimana telah disebutkan di atas bahwa model civil forfeiture adalah model yang menggunakan pembalikan beban pembuktian. Model ini merupakan model yang memfokuskan kepada gugatan terhadap aset bukan mengejar pelaku (tersangka). Penyitaan dengan menggunakan model civil forveiture ini lebih cepat setelah diduga adanya hubungan aset dengan tindak pidana, sehingga aset negara dapat diselamatkan meskipun tersangka telah melarikan diri atau meninggal dunia. Karena pada prinsipnya civil forfeture adalah "hak negara harus kembali ke negara demi kesejahteraan rakyat".

Keberhasilan penggunaan civil forfeiture di negara maju bisa dijadikan wacana bagi Indonesia karena civil forfeiture dapat memberikan keuntungan dalam proses peradilan dan untuk mengejar aset para koruptor. Seperti yang terlihat selama ini, seringkali jaksa mengalami kesulitan dalam membuktikan kasus-kasus korupsi karena tingginya standar pembuktian yang digunakan dalam kasus pidana. Selain itu, seringkali dalam proses pemidanaan para koruptor, mereka menjadi sakit, hilang atau meninggal yang dapat mempengaruhi atau memperlambat proses peradilan. Hal ini dapat diminimalisir dengan menggunakan civil forfeiture karena obyeknya adalah aset bukan koruptornya, sehingga sakit, hilang atau meninggalnya si koruptor bukan menjadi halangan dalam proses persidangan. ${ }^{48}$

Instrumen civil forfeiture menggunakan guagatan in rem yakni suatu gugatan yang substansinya merupakan perampasan terhadap harta kekayaan hasil tindak pidana korupsi secara perdata yakni dengan pemulihan kembali harta kekayaan negara yang telah dikorupsi. Berbeda dengan perampasan harta kekayaan secara pidana merupakan bagian dari pelaksanaan putusan hakim pidana dalam suatu perkara pidana, jenis perampasan harta kekayaan ini disebut juga sebagai tindakan in personam terhadap terpidana, bukan tindakan in rem terhadap harta kekayaan yang terkait dengan tidak pidana. Civil forfeiture merupakan proses gugatan terhadap aset (in rem), sehingga pelaku tindak pidana tidak relevan lagi. Jadi, instrumen civil forfeiture cukup menjanjikan dalam merampas aset korupsi karena dapat melakukan penyitaan aset melalui gugatan in rem atau gugatan terhadap aset hasil korupsi secara perdata. ${ }^{49}$

${ }^{46}$ Ibid., hlm. 7.

${ }^{47}$ Anthony Kennedy, An Evaluation of the Recovery of Criminal Proceeds in the United Kingdom”, Journal of Money Laundering Control, Vol.10, No.1, Tahun 2007, hlm. 144.

${ }^{48}$ Ibid., hlm. 26.

${ }^{49}$ Oloan Harahap, Analisis Guigatan Bersifat In Rem Terhadap Pelaku Tindak Pidana Korupsi pada Sistem Common Law, Tesis, (Medan: Program Studi Ilmu Hukum Fakultas Hukum Universitas Sumatera Utara 2009), hlm. 2. 
Upaya non penal lainnya adalah melalui pendidikan keagaaman terhadap masyarakat. Pendidikan keagamaan merupakan upaya yang massif untuk mereduksi terjadi tindak pidana korupsi. Dalam konteks ini adalah bagaimana menciptakan komunitas masyarakat yang religius sesuai dengan agama dan kepercayaannya masingmasing sehingga dapat mendorong anggota masyarakat untuk tidak melakukan korupsi. Selain itu juga, lembaga-lembaga keagamaan mempunyai landasan yang kuat untuk melibatkan para anggotanya dalam upaya penanggulangan kejahatan. Sedangkan komunitas-komunitas keagamaan ini mendorong para anggota perkumpulannya yang tersebar diseluruh belahan dunia untuk melakukan kegiatan penanggulangan kejahatan bekerjasama dengan pihak-pihak terkait. ${ }^{50}$

Menurut Tim Hope, pencegahan kejahatan oleh masyarakat (community crime prevention) mengarah kepada tindakan-tindakan yang diharapkan dapat merubah kondisi sosial yang mendukung terjadinya kejahatan di kediaman masyarakat. Fokus perhatiannya dikonsentrasikan pada kemampuan institusi sosial lokal untuk mengurangi angka kejahatan. Institusi lokal ini mewadahi anggota masyarakat dalam suatu komunitas untuk bekerjasama secara sungguh-sungguh, memberikan bimbingan dan mengatur etika berprilaku, khususnya bagi anak-anak muda. Community crime prevention ini dapat didekati melalui dua dimensi, pertama, melalui dimensi horizontal dari hubungan sosial antara orang-orang dan group-group dalam masyarakat. Kedua, melalui dimensi vertikal dari relasi sosial yang menghubungkan institusi lokal dengan komunitas yang lebih luas dari civil society. ${ }^{51}$

Terkait dengan pencegahan tindak pidana korupsi, maka program-program dari community crime prevention ini dapat diklasifikasikan sebagai berikut: ${ }^{52}$

1. Community organization, tipe ini ditujukan membangun sebuah komunitas masyarakat yang didasarkan pada kerjasama dalam penanggulangan kejahatan. Kerjasama ini juga dibina melalui sekolah-sekolah lokal, tempat-tempat ibadah.

2. Community development, strategi yang digunakan adalah membangun kembali tatanan kehidupan sosial, fisik dan perekonomian lingkungan tempat tinggal.

3. Structural change, tujuan yang ingin dicapai hampir sama dengan community development, yaitu strategi yang dibangun adalah perubahan yang utama di dalam kehidupan masyarakat yang dapat mereduksi terjadinya kejahatan. Pendekatan yang dilakukan berupa penerapan kebijakan di level makro pembangunan ekonomi dan ketenagakerjaan, perumahan yang layak, pendidikan, pelayanan kesehatan dan kesejahteraan serta pelayanan sosial.

\section{Penutup}

Kebijakan penanggulangan kejahatan (criminal policy) korupsi harus dilakukan secara integratif. Pendekatan yang integratif ini dapat dilakukan melalui dua pendekatan, yaitu pendekatan penal (penerapan hukum pidana) dan pendekatan nonpenal (pendekatan di luar hukum

${ }^{50}$ Ibid., hlm. 201

${ }^{51}$ Tim Hope, Community Crime Prevention dalam Reducing Offending: An Assessment of Research Evidence on Ways of Dealing with Offending Behaviour dalamPeter Goldblatt dan Chris Lewis (Ed.). London: Home Office, 1998, hlm. 51dan 54.

${ }^{52}$ Ibid., hlm. 56. 
pidana). Integrasi dua pendekatan ini disyaratkan dan diusulkan dalam United Nations Congress on the Prevention of Crime and the Treatment of Offenders. Hal ini dilatarbelakangi bahwa kejahatan adalah masalah sosial dan masalah kemanusiaan. Oleh karenanya upaya penanggulangan kejahatan korupsi tidak hanya dapat mengandalkan penerapan hukum pidana semata, tetapi juga melihat akar lahirnya persoalan kejahatan ini dari persoalan sosial, sehingga kebijakan sosial juga sangat penting dilakukan.

Penal policy dilakukan dengan mengevaluasi substansi peraturan perundang-undangan yang terkait dengan tindak pidana korupsi. Evaluasi ini dimaksudkan untuk menggali konsepkonsep yang bisa dijadikan bahan masukan untuk pembaharuan UU PTPK di masa depan, termasuk perampasan harta kekayaan kejahatan hasil tindak pidana korupsi dalam rangka mengembalikan kerugian keuangan Negara. Selain itu yang sangat penting dalam penal policy terhadap tindak pidana korupsi ini adalah membangun visi bersama diantara komponen Criminal Justice System (KPK, Polisi, Jaksa, Hakim, dan Lembaga pemasyaratan). Visi bersama ini diarahkan untuk mencegah dan memberantas tindak pidana korupsi dengan melahirkan kerjasama koordinatif dan saling penegrtian.

Pendekatan non penal policy dilakukan dengan membangun komunitas-komunitas masyarakat yang sadar hukum dan mau membantu aparat dalam penanggulangan tindak pidana korupsi. Kerjasama ini bisa diawali dengan melakukan mapping terhadap factor-faktor yang dapat menumbuhsuburkan korupsi, serta menemukan upaya utk mereduksi factor-faktor ini sampai ke akar-akarnya.

\section{Daftar Pustaka}

Arief, Barda Nawawi, Bunga Rampai Kebijakan Hukum Pidana. Citra Aditya Bakti, Bandung, 1996.

, Beberapa Aspek Kebijakan Penegakan dan Pengembangan Hukum Pidana. (Selanjutnya disebut buku I), Bandung: Citra Aditya Bakti, (1998).

Atmasasmita, Romli, Kapita Selekta Hukum Pidana dan Kriminologi, Mandar Maju, Bandung, 1995

Clifford, W., Reform in Criminal Justice in Asia and the Far East. Tokyo: UNAFEI, Resource Material Series No.6, 1973

Christiansen, Karl O. Some Consideration on the Possibility of a Rational Criminal Policy. Tokyo: UNAFEI, Resource Material Series No. 7, 1974

DiNitto, Diana M. Social Welfare, Politics and Public Policy. Boston: Allyn \& Bacon, 2000

Effendy, Marwan, Pengadilan Tindak Pidana Korupsi, Lokakarya, Anti-korupsi bagi Jurnalis, Surabaya, 2007

Friedman, Lawrence M.. American Law an Introduction. (Selanjutnya disebut buku I). New York: W.W. Norton \& Company, 1984 
The Legal System; A Social Science Perspective. (Selanjutnya di sebut buku II). New York: Russel Sage Foundation, 1975

Eigth United Nations Congress on on the Prevention of Crime and the Treatment of Offenders. New York: Departement of Economic and Social Affairs, UN, 1991

Fourth United Nations Congress, on the Prevention of Crime and the Treatment of Offenders. New York: Departement of Economic and Social Affairs, UN, 1971

Fifth United Nations Congress. on the Prevention of Crime and the Treatment of Offenders. New York: Departement of Economic and Social Affairs. 1976

Hoefnagels, G. Pieter, The Other Side of Criminology, An Inversion of The Concept of Crime. Holland: Kluwer Deventer, 1972

Harahap, Oloan, Analisis Guigatan Bersifat In Rem Terhadap Pelaku Tindak Pidana Korupsi pada Sistem Common Law, Tesis, (Medan: Program Studi Ilmu Hukum Fakultas Hukum Universitas Sumatera Utara 2009).

Kennedy, Anthony, An Evaluation of the Recovery of Criminal Proceeds in the United Kingdom", Journal of Money Laundering Control, Vol.10, No.1, Tahun 2007.

Lubis, Solly. Serba Serbi Politik dan Hukum. Mandar Maju, Bandung, 1989

Said, Sudirman, dan Nizar Suhendra, Korupsi dan Masyarakat Indonesia dalam Mencuri Uang Rakyat, 16 Kajian Korupsi di Indonesia, Buku I Dari Puncak sampai Dasar. Hamid Basyaib et.al (Ed). Jakarta: Yayasan Aksara, 2002

Sixth United Nations Congress. on the Prevention of Crime and the Treatment of Offenders. New York: Departement of Economic and Social Affairs, UN. 1981

Seventh United Nations Congress. on the Prevention of Crime and the Treatment of Offenders. New York: Departement of Economic and Social Affairs, UN. 1986

Soedarto, Hukum dan Hukum Pidana. Alumni, Bandung, 1981

Hukum Pidana dan Perkembangan Masyarakat. Sinar Baru. Bandung, 1983

Soewartojo, Juniadi, Korupsi, Pola Kegiatan dan Penindakannya Serta Peran Pengawasan Dalam Penanggulangannya, Balai Pustaka, Jakarta, 1998

Yanuar, Purwaning M., Pengembalian Aset Hasil Korupsi Berdasarkan Konvensi PBB Anti Korupsi 2003 Dalam Sistem Hukum Indonesia, Alumni, Bandung, 2007

UNAFEI, Tokyo: Resource Material Series No. 22. 
Volume 13, Nomor 1, Januari-Juni 2018

Tim Hope Community Crime Prevention dalam Reducing Offending: An Assessment of Research Evidence on Ways of Dealing with Offending Behaviour dalamPeter Goldblatt dan Chris Lewis (Ed.). London: Home Office. (1998 